\title{
Hubungan Preeklamsia dengan Kejadian BBLR di RSU Kabupaten Tangerang Tahun 2018
}

\author{
Relationship between Preeclampsia and Low Birth Weight in RSU Kabupaten \\ Tangerang Year 2018
}

\author{
Astrisa Faadhillah ${ }^{\mathrm{a}^{*}}$, Helda $^{\mathrm{b}}$ \\ $\mathrm{a}^{*}$ Prodi Pendidikan Sarjana dan Profesi Kebidanan Fakultas Ilmu Kesehatan Universitas Muhammadiyah Tangerang, Indonesia \\ ${ }^{\mathrm{b}}$ Departemen Epidemiologi, Fakultas Kesehatan Masyarakat Universitas Indonesia, Lantai 1 Gedung A, Kampus UI Depok, Indonesia
}

\section{A B S T R A K}

Berat badan lahir rendah didefinisikan oleh World Health Organization. sebagai berat saat lahir kurang dari 2500 gram. Bayi dengan berat badan lahir rendah (BBLR) meningkatkan angka kesakitan dan kematian dua kali lipat dibandingkan dengan bayi yang lahir dengan berat badan 2500 gram atau lebih. Berat lahir rendah menjadi masalah kesehatan masyarakat berkelanjutan secara signifikan dan global dikaitkan dengan serangkaian konsekuensi jangka pendek dan jangka panjang. Faktor resiko utama yang berhubungan dengan tingginya kejadian BBLR adalah faktor demografi, penyakit kronis sebelum hamil, status gizi ibu hamil, komplikasi dalam kehamilan, dan status pemeriksaan kehamilan. Metode yang digunakan dalam penelitian ini adalah cross sectional. Penelitian ini menggunakan analisis cox regression dengan hasil ukur prevalence ratio (PR). Hasil penelitian ini menemukan bahwa terdapat hubungan yang signifikan antara preeklamsia dengan kejadian BBLR dengan $P$ value $=0,001$ dengan nilai PR adjusted 1,483 (CI 95\% 1,192$1,846)$ setelah dikontrol oleh variabel Confounding. Variabel confounding adalah usia hamil, oligohidramnion, dan IUFD dengan nilai ÄPR $>10 \%$. Angka kejadian BBLR berhubungan dengan penanganan kasus preeklamsia dan eklamsia yang gawat memerlukan tindakan aktif, yaitu terminasi kehamilan segera tanpa memandang usia kehamilan dan perkiraan berat badan janin sehingga dapat melahirkan bayi dengan berat badan lahir rendah. Oleh sebab itu, sangat diperlukan pemantauan oleh tenaga kesehatan terhadap ibu-ibu yang mengalami komplikasi dalam kehamilannya terutama yang memiliki tekanan darah yang tinggi dalam kehamilannya agar dapat ditangani secara dini dan dilakukan perawatan konservatif sehingga kejadian BBLR dapat dicegah.

Kata kunci: bayi, BBLR, preeklamsia, Tanggerang

\section{A B S T R A C T}

Low birth weight is defined by the World Health Organization. as a weight at birth less than 2500 grams. Babies with low birth weight (LBW) have twice the risk for morbidity and mortality compared with babies born with a weight of 2500 grams or more. Low birth weight is a significant and globally sustainable public health problem associated with a series of short-term and long-term consequences. The main risk factors that associated with the high incidence of LBW are demographic factors, chronic illness before pregnancy, nutritional status of pregnant women, complications in pregnancy, and the status of antenatal care. This study was cross sectional study design and used cox regression analysis with the results of measuring was prevalence ratio (PR). The Result there was significant relationship between preeclampsia and LBW incidence with P-value $=0.001, \mathrm{PR}$ value adjusted 1.483 (95\% CI 1.192-1.846) after controlled by the Confounding variable. Confounding variables were pregnancy age, oligohydramnios, and IUFD with ÄPR $>10 \%$. LBW incidence rates are associated with the treatment of severe preeclampsia and eclampsia that require active action, namely immediate termination of the pregnancy regardless of gestational age and estimated fetal body weight so that a baby with low birth weight can be born. Therefore, it is very necessary for monitoring by health workers on mothers who complications in pregnancy before, especially mother with high blood pressure in pregnancy so that it can be treated early, conservative care and LBW events can be prevented.

Key words: Infant, LBW, preeclampsia, Tanggerang

Dalam tulisannya, Reyes dan Manalich menyampaikan sejumlah penelitian menunjukkan bahwa paparan lingkungan intrauterin yang tidak normal memengaruhi perkembangan antropometrik, metabolisme, dan mental, yang mengarah pada peningkatan resiko penyakit di kemudian hari. ${ }^{3}$ Penelitian yang dilakukan pada bayi BBLR yang dievaluasi hingga usia 30 bulan didapatkan setengahnya memiliki disabilitas pada motorik, kognitif, dan saraf sensorik. Kecacatan parah pada anak usia dini umumnya bertahan di usia sekolah. Sebanyak $86 \%$ bayi

*Korespondensi: Astrisaf Faadhilla, Prodi Pendidikan Sarjana dan Profesi Kebidanan Fakultas Ilmu Kesehatan Universitas Muhammadiyah Tangerang. Indonesia. Email: astrisaf@gmail.com HP: 081381001653 
dengan cacat berat pada usia 30 bulan dan memiliki cacat sedang hingga parah pada usia 6 tahun. ${ }^{3}$

Data RISKESDAS (Riset Kesehatan Dasar) pada tahun 2018 memperlihatkan proporsi BBLR di Indonesia menempati angka 6,2\%, sedangkan di Banten memiliki angka proporsi 6,7\%. Data Dinas Kesehatan Kabupaten Tangerang tahun 2018 menyampaikan bahwa angka kejadian BBLR adalah sebanyak 1635 $(14,7 \%)$. Penelitian dengan hospital based di RSU kelas B Kabupaten Subang didapatkan prevalensi BBLR 29,24\%. ${ }^{4}$ Penelitian di RSU dr. Soekardjo Tasikmalaya menyatakan bahwa prevalensi BBLR sebesar 29,61\%. ${ }^{5}$ Sedangkan prevalensi BBLR pada penelitian di RSU Anutapura Palu sebesar 50\%. ${ }^{6}$

Persentase ibu yang melahirkan bayi BBLR dalam dua tahun terakhir di Indonesia berdasarkan karakteristik ibu sebanyak 13\% dengan angka terendah berada di Indonesia bagian barat (8,48\%) dan tertinggi di Indonesia bagian timur adalah 17,75\%.7 Prevalensi kejadian BBLR pada ibu dengan preeklamsia yang terjadi sebelum 34 minggu usia kehamilan lebih rendah (23\%) dibandingkan dengan prevalensi BBLR pada ibu dengan preeklamsia yang terjadi diatas 34 minggu usia kehamilan sebanyak 53\%. ${ }^{8}$ Hasil luaran prematur dibawah usia gestasi 37 minggu dari ibu yang mengalami preeklamsia adalah sebanyak 46\%, <35 minggu sebanyak $22 \%$. Sedangkan yang lahir dengan status neonatus kecil masa kehamilan sebanyak $8 \% .{ }^{9}$ Penelitian terbaru menyatakan bahwa prevalensi BBLR pada ibu preeklamsia adalah sebesar $68,5 \% .^{10}$

Preeklamsia dapat menyebabkan masalah pada organ hati, ginjal, dan otak, serta kelainan pada sistem pembekuan darah. Komplikasi ini juga melibatkan plasenta, yang meningkatkan risiko bagi janin. Kelainan yang paling umum adalah pertumbuhan yang buruk pada janin sebagai akibat dari pasokan darah yang tidak memadai melalui plasenta yang rusak, dan masalah prematuritas (terkait baik dengan persalinan prematur spontan atau kelahiran dini dengan induksi atau dengan sectio caesaria untuk melindungi ibu atau janin). ${ }^{11}$

Rumah Sakit Umum Daerah Kabupaten Tangerang merupakan salah satu fasilitas kesehatan milik pemerintah dan termasuk Rumah Sakit Rujukan Sistem Informasi Jejaring Rujukan Maternal dan Neonatal (Sijari Emas) untuk mengurangi tingkat kematian ibu dan bayi baru lahir dan seringkali dijadikan pilihan rujukan masalah kebidanan, khususnya dengan kasus preeklamsia. Menurut data statistik RSUD Tangerang jumlah kematian ibu di RS tersebut pada tahun 2010 sebanyak 35 kasus, dengan penyebab utama yaitu PEB $(22,8 \%)$, Eklamsia (20\%), Syok Hipovolemik (17\%), Sepsis $(11,4 \%)$, lain-lain $(28,7)$. Sedangkan angka kejadian preeklampsia di
RSUD Tangerang pada tahun 2010, sebanyak 817 kasus $(16,5 \%){ }^{12}$

\section{Metode}

Desain penelitian yang digunakan dalam penelitian ini adalah cross sectional. Penelitian ini dilakukan di Rumah Sakit Umum Kabupaten Tangerang. Penelitian dilakukan dengan mengumpulkan data sekunder RSU Kabupaten Tangerang dimulai pada bulan Mei-Juni 2019. Semua data yang diperoleh dijaga kerahasiaannya dikarenakan tidak menggunakan kode nama atau nomor identitas untuk menandai individu, melainkan dengan kode angka. Populasi dalam penelitian ini adalah seluruh ibu melahirkan di RSU Kabupaten Tangerang tahun 2018. Teknik pengambilan sampel dengan cara total sampling, yaitu seluruh ibu melahirkan di RSU Kabupaten Tangerang tahun 2018. Jumlah sampel dalam penelitian ini sebanyak 1036 yang terbagi dalam kelompok terpajan sebanyak 242 responden dan kelompok tidak terpajan sebanyak 794 responden. Variabel yang diukur adalah berat bayi saat lahir, usia kehamilan saat ibu melahirkan, riwayat preeklamsia sebelum dan saat melahirkan, riwayat ketuban pecah dini saat melahirkan, riwayat oligohidramnion, hamil kembar, dan apakah janinnya mengalami IUGR. Pengolahan data menggunakan SPSS dan STATA dengan langkah screening, editing, coding, dan entry. Analisis data menggunakan uji statistik cox regression dengan hasil ukur prevalence ratio (PR).

\section{Hasil}

Tabel 1. Distribusi Frekuensi Variabel Penelitian

\begin{tabular}{lcc}
\hline Variabel & Frequency & \% \\
\hline Berat Bayi Lahir & & \\
BB $\geq 2500$ gr & 672 & 64,9 \\
BB <2500 gr & 364 & 35,1 \\
Preeklamsia & & \\
Tidak & 794 & 76,6 \\
Ya & 242 & 23,4 \\
Usia Kehamilan & & \\
$\geq 37$ Minggu & 666 & 64,3 \\
$<37$ Minggu & 370 & 35,7 \\
Ketuban Pecah Dini & & \\
Tidak & 866 & 83,6 \\
Ya & 170 & 16,4 \\
Oligohidramnion & & \\
Tidak & 941 & 90,6 \\
Ya & 95 & 9,2 \\
Kehamilan Gemeli & & \\
Tidak & 997 & 96,2 \\
Ya & 39 & 3,8 \\
IUGR & & \\
Tidak & 1019 & 98,4 \\
Ya & 17 & 1,6 \\
\hline
\end{tabular}


Faadhillah \& Helda, Hubungan Preeklamsia dengan Kejadian BBLR di RSU Kabupaten Tangerang Tahun 2018

Tabel 2. Hasil Bivariat Faktor Resiko Terhadap BBLR

\begin{tabular}{|c|c|c|c|c|c|c|c|c|}
\hline Variabel & $\mathbf{N}$ & $=2500 \mathrm{gr}$ & $\%$ & $<2500 \mathrm{gr}$ & $\%$ & P Value & PR & CI 95\% \\
\hline Preeklamsia & & & & & & 0,001 & 2,003 & $1,715-2,340$ \\
\hline Tidak & 794 & 568 & 84,5 & 226 & 62,1 & & & \\
\hline Ya & 242 & 104 & 15,5 & 138 & 37,9 & & & \\
\hline Usia Kehamilan & & & & & & 0,001 & 8,767 & $6,883-11,167$ \\
\hline$\geq 37$ Minggu & 666 & 604 & 89,9 & 62 & 17,0 & & & \\
\hline$<37$ Minggu & 370 & 68 & 10,1 & 302 & 83,0 & & & \\
\hline Ketuban Pecah Dini & & & & & & 0,962 & 1,005 & $0,804-1,256$ \\
\hline Tidak & 866 & 562 & 83,6 & 304 & 83,5 & & & \\
\hline Ya & 170 & 110 & 16,4 & 60 & 16,5 & & & \\
\hline Oligohidramnion & & & & & & 0,001 & 1,725 & $1,747-4,114$ \\
\hline Tidak & 941 & 631 & 93,9 & 310 & 85,2 & & & \\
\hline $\mathrm{Ya}$ & 95 & 41 & 6,1 & 54 & 14,8 & & & \\
\hline Kehamilan Gemeli & & & & & & 0,001 & 2,979 & $2,689-3,301$ \\
\hline Tidak & 997 & 671 & 99,9 & 326 & 89,6 & & & \\
\hline $\mathrm{Ya}$ & 39 & 1 & 0,1 & 38 & 10,4 & & & \\
\hline IUGR & & & & & & 0,001 & 2,220 & $1,682-2,928$ \\
\hline Tidak & 1019 & 668 & 99,4 & 351 & 96,4 & & & \\
\hline $\mathrm{Ya}$ & 17 & 4 & 0,6 & 13 & 3,6 & & & \\
\hline
\end{tabular}

Berdasarkan tabel 1 diketahui dari 1036 sampel penelitian, sebanyak $242(23,4 \%)$ ibu yang melahirkan di RSU Kabupaten Tangerang yang mengalami preeklamsia dan ibu yang melahirkan bayi BBLR sebanyak 364 (35,1\%). Distribusi frekuensi variabel confounding diketahui Ibu yang melahirkan pada usia kehamilan $<37$ minggu adalah 370 orang $(35,7 \%)$. Ketuban pecah dini adalah 170 (16,4\%). Sedangkan ibu dengan oligohidramnion sebanyak 95 orang $(9,2 \%)$. Subjek penelitian dengan status kehamilan gemeli sebanyak 39 orang $(3,8 \%)$. Ibu yang mengalami IUGR sebanyak 17 orang $(1,6 \%)$.

Tabel 2 adalah hasil analisis bivariat antara BBLR sebagai variabel dependen dengan preeklamsia sebagai variabel independen dan juga BBLR dengan variabel confounding. Dari analisis bivariat didapatkan hasil bahwa preeklamsia memiliki hubungan yang signifikan kejadian BBLR dengan hasil $p$ value $<0,05$ dan nilai PR 2,003 (CI 95\% 1,715-2,340). Artinya ibu dengan preeklamsia beresiko 2,003 kali memiliki bayi BBLR.

Tabel 3. Model Awal Hubungan Preeklamsia dengan Kejadian BBLR di RSU Kabupaten Tangerang Tahun 2018

\begin{tabular}{llll}
\hline Variabel & P value & PR & CI 95\% \\
\hline Preeklamsia & 0,0001 & 1,497 & $1,207-1,856$ \\
Usia hamil & 0,731 & 0,963 & $0,777-1,194$ \\
KPD & 0,593 & 0,923 & $0,689-1,237$ \\
Oligohidramnion & 0,170 & 1,238 & $0,913-1,679$ \\
Kehamilan gemeli & 0,047 & 1,663 & $1,007-2,749$ \\
IUGR & 0,028 & 1,880 & $1,072-3,299$ \\
\hline
\end{tabular}

Berdasarkan tabel 2 juga dapat dilihat variabel lain yang memiliki hubungan dengan BBLR adalah usia kehamilan (PR 8,767 CI 95\% 6,883-11,167), oligohidramnion (PR 1,725 CI 95\% 1,747-4,114), kehamilan kembar (gemeli) (PR 2,979 CI 95\% 2,6893,301), dan IUGR (PR 2,220 CI 95\% 1,682$2,928)$.Variabel yang tidak berhubungan dengan kejadian BBLR karena memiliki nilai $p$ value $>0,05$ adalah ketuban pecah dini.

Tabel Model Akhir Hubungan Preeklamsia dengan Kejadian BBLR di RSU Kabupaten Tangerang Tahun 2018

\begin{tabular}{llll}
\hline Variabel & P value & PR & CI 95\% \\
\hline Preeklamsia & 0,001 & 1,488 & $1,201-1,842$ \\
Usia hamil & 0,001 & 7,823 & $5,918-10,342$ \\
Oligohidramnion & 0,147 & 1,241 & $0,927-1,661$ \\
Kehamilan gemeli & 0,031 & 1,456 & $1,034-2,050$ \\
IUGR & 0,020 & 1,934 & $1,108-3,377$ \\
\hline
\end{tabular}

Hasil analisis multivariat didapatkan bahwa preeklamsia berhubungan dengan kejadian BBLR dengan nilai $p$ value 0,001 PR 1,497 (CI 95\% 1,2071,856).

Faktor yang dapat mempengaruhi terjadinya preeklamsia yaitu usia hamil, kehamilan gemeli, dan IUGR yang dapat menyebabkan BBLR. Dalam penelitian ini PR tidak ada yang $>10 \%$ sehingga variabel yang didapatkan pada model akhir ini merupakan variabel yang secara substansi mempengaruhi kejadian BBLR walaupun secara statistik tidak dapat membuktikan sebagai confounding. 


\section{Pembahasan}

Pada penelitian ini terdapat beberapa keterbatasan dan kelemahan yang bisa mempengaruhi hasil penelitian. Penelitian ini bertujuan untuk mengetahui hubungan preeklamsia dengan kejadian BBLR di RSU Kabupaten Tangerang tahun 2018. Data yang digunakan merupakan data sekunder rekam medik RSU Kabupaten Tangerang tahun 2018 yang diakses langsung pada data rekam medik atas izin dari RSU Kabupaten Tangerang. Data yang terdapat dalam rekam medik tidak semua tersedia seperti yang dibutuhkan peneliti tersedia sehingga peneliti menyesuaikan dengan ketersedian data yang ada. Penelitian ini menggunakan desain cross sectional dimana eksposure dan outcome diukur pada waktu yang bersamaan. Bias seleksi merupakan distorsi efek yang muncul akibat cara memilih subyek penelitian atau hilangnya subyek sebelum menjadi unit analisis. Pada penelitian ini terdapat 17 responden yang data rekam medis nya tidak lengkap atau tidak ditemukan, serta 6 responden dengan abortus.

Pada penelitian ini peneliti menggunakan data rekam medis RSU Kabupaten Tangerang tahun 2018, dimana subyek yang dibutuhkan dalam penelitian ini adalah seluruh ibu yang melahirkan di RSU Kabupaten Tangerang tahun 2018. Bias seleksi dalam penelitian ini relatif minim terjadi. Penelitian ini menggunakan data sekunder data rekam medik untuk mendapatkan variabel yang dibutuhkan peneliti. Pengisian rekam medis dilakukan oleh tenaga medis sekaligus subjek yang melakukan penatalaksanaan medis. Sehingga kecil kemungkinan untuk terjadinya bias informasi. Hasil penelitian ini dapat digeneralisasi pada populasi target yaitu ibu yang melahirkan di RSU atau kelompok yang mempunyai karakteristik yang sama dengan sampel sehingga bisa mewakili populasi umum.

Hasil penelitian ini menemukan bahwa terdapat hubungan yang signifikan antara preeklamsia dengan kejadian BBLR dengan $p$ value $=0,001(\mathrm{p}<0,05)$. Besar asosiasi PR 1,483 dengan 95\% CI (1,21-1,86). Artinya ibu dengan preeklamsia memiliki resiko 1,483 memiliki bayi dengan BBLR.

Hasil penelitian ini sejalan dengan hasil penelitian yang dilakukan oleh Ota et al (2014) yang menemukan adanya hubungan preeklamsia dengan kejadian BBLR memiliki nilai $p$ value $=0,001$ dan nilai OR 2,05 (CI 95\% 1,18-2,23). ${ }^{13}$ Penelitian lain yang dilakukan di India menemukan bahwa prevalensi BBLR pada ibu yang preeklamsia adalah sebnayak $60 \%{ }^{14}$ Khader et al (2017) dalam penelitiannya mendapatkan bahwa prevalensi kejadian BBLR pada ibu yang preeklamsia sebanyak $68,5 \%$ dengan nilai $p$ value $=$ $0,001(\mathrm{p}<0,05)$.
Sejumlah penelitian menunjukkan bahwa paparan lingkungan intrauterin yang tidak normal memengaruhi perkembangan antropometrik, metabolisme, dan mental, yang mengarah pada peningkatan risiko penyakit di kemudian hari. ${ }^{15}$

Lim, et al dalam Lafayette mengatakan, pemeriksaan patologis plasenta dari kehamilan preeklamsia umumnya mengungkapkan infark plasenta dan penyempitan sklerotik arteri dan arteriol, dengan karakteristik berkurangnya invasi endovaskular oleh sitotrofoblas dan remodeling arteri uterina spiral yang tidak adekuat. ${ }^{16}$

Meskipun perubahan patologis umumnya tidak selalu terlihat pada plasenta wanita dengan preeklamsia, profil plasenta termasuk pemeriksaan doppler arteri uterina yang abnormal dan morfologi plasenta telah digunakan untuk mengidentifikasi subset dari kelompok wanita yang berisiko tinggi terhadap berkembangnya sindrom tersebut. Pasien dengan kelainan bentuk arteri uterin unilateral atau bilateral memiliki berat lahir rata-rata yang lebih rendah $(\mathrm{p}=$ $0,01)$, tingkat preeklampsia yang lebih tinggi $(p=0,01)$, tingkat SGA yang lebih tinggi $(p=0,001)$, dan operasi caesar $(p=0,001) \cdot{ }^{17}$

Menurut Moussa, Arian, dan Sibai (2014) dalam Peres (2018), preeklamsia adalah penyakit yang bersifat multisistemikyang ditandai dengan hipertensi yang berkembang setelah masa kehamilan 20 minggu dimana sebelumnya normal, dengan disertai proteinuria atau, jika tidak ada, disertai dengan tanda gejala cedera organ. ${ }^{18}$

Lindheimer, Taler, dan Cunningham (2008), menyatakan bahwa preeklamsia paling tepat digambarkan sebagai sindrom khusus-kehamilan yang dapat mengenai setiap sistem organ. Meskipun preeklamsia lebih dari sekedar hipertensi gestasional sederhana ditambah proteinuria. Timbulnya proteinuria tetap merupakan kriteria diagnostik objektif yang penting. Proteinuria didefinisikan sebagai ekskresi protein dalam urin yang melebihi 300 mg dala 24 jam, rasio protein: kreatinin urin e" 0.3 , atau adanya protein sebanyak $30 \mathrm{mg} / \mathrm{dL}$ (carik celup $1+$ ) dalam sampel acak urin secara menetap. ${ }^{19}$

Angka kejadian BBLR berhubungan dengan penanganan kasus preeklamsia dan eklamsia yang gawat memerlukan tindakan aktif, yaitu terminasi kehamilan segera tanpa memandang usia kehamilan dan perkiraan berat badan janin sehingga dapat melahirkan bayi dengan berat badan lahir rendah. Oleh sebab itu, sangat diperlukan pemantauan oleh tenaga kesehatan terhadap ibu-ibu yang mengalami komplikasi dalam kehamilannya terutama yang memiliki tekanan darah yang tinggi dalam kehamilannya agar dapat ditangani secara dini dan 
dilakukan perawatan konservatif sehingga kejadian BBLR dapat dicegah ${ }^{4}$

Untuk pencegahan preeklamsia, satu-satunya terapi efektif yang saat ini diketahui adalah dosis rendah aspirin. Beberapa pedoman internasional, termasuk yang dari Organisasi Kesehatan Dunia (WHO), telah melaporkan bahwa, dari 12 minggu kehamilan sampai kelahiran, dosis 75-100 mg aspirin harus diresepkan. Penatalaksanaan pre-eklamsia ringan dimaksudkan untuk mencegah evolusi menjadi preeklamsia berat, untuk menetapkan waktu persalinan, dan untuk mengevaluasi perkembangan paru janin. Dalam kasus preeklamsia berat, tujuannya adalah pencegahan eklamsia (kejang), kontrol tekanan darah yang ketat, dan perencanaan persalinan. ${ }^{18}$

Menurut Lou (2005) Penyebab BBLR sangat kompleks dan waktu yang cukup lama. Penyebab salah satunya yaitu preeklamsia yang diawali dengan kelainan pembentukan pembuluh darah yang dapat menyebabkan BBLR karena IUGR atau terminasi diawal kehamilan (prematur). ${ }^{20}$ Berat badan bayi merupakan interaksi dari beberapa faktor baik faktor internal maupun faktor eksternal melalui suatu proses selama berada dalam kandungan. ${ }^{5}$ Faktor internal yang mempengaruhi berat badan lahir diantaranya adalah usia ibu saat hamil, umur kehamilan, paritas, gizi selama kehamilan, status dan penyakit penyerta misalnya diabetes mellitus, TORCH, hipertensi termasuk preeklamsia dan eklamsia. ${ }^{5}$

Pada wanita dengan onset terjadinya preeklamsia dengan usia kehamilan di bawah 24 minggu akan menunjukkan hasil yang buruk apabila dilakukan manajemen konservatif. Dua puluh lima hingga enam puluh tiga persen dari wanita dengan manajemen konservatif pada usia kehamilan pada trimester dua akan mengalami komplikasi yang serius seperti sindroma HELLP (Hemolysis, Elevated Liver enzymes, Low Platelet count), insufisiensi renal, solusio plasenta, edema pulmonum, dan eklamsia. Angka survival pada neonatus dengan usia kehamilan 25 minggu mencapai $70 \% .{ }^{21}$

Pasien preeklamsia dengan usia gestasi $<34$ minggu menunjukkan bahwa manajemen konservatif memiliki hubungan dengan peningkatan kondisi perinatal tanpa meningkatkan risiko terhadap ibu. Namun, manajemen konservatif ini dapat dilakukan hanya ketika tekanan darah relatif mudah dikontrol dengan obat antihipertensi dan kondisi maternal yang tidak membutuhkan magnesium sulfat. Kelahiran dilakukan segera ketika terjadi eklampsia, disfungsi multi organ, IUGR (Intra Uterine Growth Restriction), atau hasil tes fetal yang abnormal. ${ }^{21}$ Meskipun persalinan adalah yang terbaik untuk ibu, tetapi mungkin bukan yang terbaik untuk janin yang sangat prematur. Keputusan antara kelahiran dan manajemen konservatif tergantung pada usia kehamilan janin, status janin, dan tingkat keparahan kondisi ibu pada saat penilaian.

Penurunan volume cairan amnion atau oligohidramnion berhubungan dengan kondisi ibu atau janin seperti pada keadaan hipertensi, pertumbuhan janin terhambat atau kelainan bawaan, sindroma aspirasi meconium, skor APGAR rendah. Sedangkan luaran perinatal yang terkait dengan oligohidramnion berhubungan dengan kondisi mendasar dimana proses alamiahnya masih belum jelas. ${ }^{22}$

Pertumbuhan janin terhambat (IUGR) terjadi pada sekitar $5 \%$ sampai $7 \%$ dari kehamilan, dan menghasilkan bayi yang lahir pada berat lahir yang mengukur kurang dari 3\% hingga 10\% menggunakan kurva pertumbuhan standar. Pembatasan pertumbuhan disebabkan oleh pasokan nutrisi yang tidak mencukupi dan / atau pasokan oksigen yang terbatas ke janin. Mayoritas retardasi pertumbuhan janin terjadi pada pembatasan pertumbuhan metrik, sedangkan pada sekitar 20\% hingga trimester ke-3 (70\% hingga 80\%) yang mengakibatkan perumbuhan janin terhambat yang terjadi pada tanggal 1 atau 2 trimester, menghasilkan pembatasan pertumbuhan 'simetris'. ${ }^{23}$

Kejadian IUGR simetris biasanya disebabkan oleh malformasi kromosom dan kongenital, infeksi awal janin, obat-obatan atau timbulnya preeklampsia berat, dan menghasilkan tingkat morbiditas dan mortalitas yang lebih tinggi dibandingkan dengan IUGR asimetris, yang biasanya disebabkan oleh tali pusat plasenta. kelainan dan faktor vaskular ibu, serta faktor sosial ekonomi dan gizi. ${ }^{24}$

Ibu didaerah tertinggal dalam hal ekonomi dan pendidikan memiliki kesenjangan besar dalam layanan kesehatan, khususnya untuk ibu dan bayi, memiliki angka tinggi hasil neonatal yang mengkhawatirkan seperti pertumbuhan janin terhambat (IUGR), yang dimanifestasikan sebagai neonatus dengan berat lahir rendah (BBLR) atau kecil untuk usia kehamilan (SGA). ${ }^{25}$

\section{Kesimpulan dan Saran}

Penelitian ini menemukan hubungan yang signifikan antara preeklamsia dengan kejadian BBLR setelah dikontrol variabel confounding (usia kehamilan, ketuban pecah dini, oligohidramnion, kehamilan gemeli, dan IUGR). Pentingnya mencegah dimulai dari faktor resiko yang dapat menimbulkan BBLR diawali dengan pemantauan yang berkelanjutan selama masa kehamilan hingga melahirkan. Pencegahan BBLR dengan berbagai faktor resiko diharapkan dapat ditingkatkan mengingat buruknya efek jangka pendek maupun jangka panjang. Skrining 
pada ibu hamil yang memiliki potensi preeklamsia dipantau dan di terapi dengan baik sehingga memiliki efek minimal baik pada ibu maupun pada janinnya. Hasil penelitian ini dapat menjadi dasar untuk penelitian berikutnya di Banten bahkan Indonesia dengan menyertakan variabel yang belum diteliti yaitu umur, pendidikan, pekerjaan, gizi ibu, keberdayaan wanita, status perkawinan, jumlah kunjungan ANC, kualitas ANC, dan penggunaan KB.

\section{Daftar Pustaka}

1. Gopalan S. Low birth weight - causes, consequences and interventions to achieve reduction. Proc Indian Natl Sci Acad. 2018;84(4):843-51.

2. UNICEF. Cause of death 2018-1 [Internet]. 2019. Available from: data@unicef.org\%09\%0A

3. Wood NS, Marlow N, Costeloe K, Gibson AT, Wilkinson AR. Neurologic and Developmental Disability After Extremely. 2000;343.

4. Mulyanti. Hubungan Antara Komlikasi Kehamilan dengan Kejadian BBLR di RSUD Kelas B Kabupaten Subang. J Univ Padjajaran. 2010;145-50.

5. Nurliawati E. Hubungan Antara Preeklamsia dengan prematuritas. J Kesehat Bakti Tunas Husada. 2014;12(1).

6. Lisnawati L, Nadyar Humairah N, Maineny A. Preeklamsia Dan Bayi Berat Lahir Rendah (Bblr) Di Rsu Anutapura Palu. Poltekita J Ilmu Kesehat. 2019;13(1):42-7.

7. BPS. Profil Kesehatan Ibu dan Anak [Internet]. 2018 [cited 2019 May 2]. Available from: https://www.bps.go.id.

8. Odegard RA, Vatten LJ, Nilsen ST, Salvesen KÅ, Austgulen R. Preeclampsia and fetal growth. Obstet Gynecol. 2000;96(6):950-5.

9. Hnat MD, Sibai BM, Caritis S, Hauth J, Lindheimer MD, MacPherson $C$, et al. Perinatal outcome in women with recurrent preeclampsia compared with women who develop preeclampsia as nulliparas. Am J Obstet Gynecol [Internet]. 2002 Mar [cited 2019 Apr 12];186(3):422-6. Available from: http: / / linkinghub.elsevier.com/retrieve / pii / S0002937802620174

10. Khader YS, Batieha A, Al-njadat RA, Hijazi SS. Preeclampsia in Jordan: incidence, risk factors, and its associated maternal and neonatal outcomes. J Matern Neonatal Med [Internet]. 2017 Mar 19 [cited 2019 Jun 14];31(6):770-6. Available from: https://www.tandfonline.com/doi/full/10.1080/ 14767058.2017.1297411

11. Duley L. The Global Impact of Pre-eclampsia and Eclampsia. YSPER [Internet]. 2009 [cited 2018 Sep 15];33:130-7.

12. Octasila R, Yosalina R, Nofita R. Faktor resiko preeklampsia dirsu tangerang. 2013;
13. Ota E, Ganchimeg T, Morisaki N, Vogel JP, Pileggi C, OrtizPanozo E, et al. Risk Factors and Adverse Perinatal Outcomes among Term and Preterm Infants Born Smallfor-Gestational-Age: Secondary Analyses of the WHO MultiCountry Survey on Maternal and Newborn Health on behalf of the WHO Multi-Country Survey on Maternal and Newborn . 2014 [cited 2019 Apr 20]; Available from: www.plosone.org 14. Doddamani UG, Doddamani GB. Perinatal Outcome in PreEclampsia: A Prospective Study. Sch J Appl Med Sci Sch J App Med Sci [Internet]. 2014 [cited 2019 Jun 29];2(1C):2913. Available from: www.saspublisher.com

15. Reyes L, Mañalich R. Long-term consequences of low birth weight. In: Kidney International, Supplement 2005.

16. Hladunewich M, Karumanchi SA, Lafayette R. Pathophysiology of the Clinical Manifestations of Preeclampsia. Clin J Am Soc Nephrol [Internet]. 2007;2(3):543-9. Available from: http:// cjasn.asnjournals.org/cgi/doi/10.2215/CJN.03761106

17. Hershkovitz R, De Swiet M, Kingdom J. Mid-trimester placentation assessment in high-risk pregnancies using maternal serum screening and uterine artery Doppler. Hypertens Pregnancy. 2005;24(3):273-80.

18. Miguel Peres G, Mariana M, Cairrão E. Pre-Eclampsia and Eclampsia: An Update on the Pharmacological Treatment Applied in Portugal †. 2018 [cited 2018 Dec 21]; Available from: www.mdpi.com/journal/jcdd

19. Lindheimer MD, Taler SJ, Cunningham FG. Hypertension in pregnancy. JASH [Internet]. 2008 [cited 2019 Mar 23];2:484-94. Available from: https:// www.ashjournal.com/article/S1933-1711(08)00185-X/pdf 20. Cunningham FG, Leveno KJ, Bloom SL, Spong CY, Dashe JS, Hoffman BL, et al. Universal Free E-Book Store Universal Free E-Book Store. 2014.

21. Lumbanraja SN. MANAJEMEN KONSERVATIF PADA PREEKLAMSIA [Internet]. 2018 [cited 2019 Feb 19]. Available from: http://cursoenarm.net/UPTODATE/contents / mobipreview.htm?16/50/17184

22. Lumentut A, Tendean HMM. Resiko maternal dan luaran perinatal dengan oligohidramnion di BLU RSU Prof. DR. R. Kandau Manado. J Kedokt Komunitas dan Trop. 2015;3(3):129-33.

23. Kirch W. Encyclopedia of Public Health. 2008.

24. Brodsky D, Christou H, Israel B. Current Concepts in Intrauterine Growth Restriction. J Intensive Care Med [Internet]. 2004 [cited 2019 Jun 21];19:307-19. Available from: https://journals.sagepub.com/doi/pdf/10.1177/ 0885066604269663

25. Sadovsky ADI, Matijasevich A, Santos IS, Barros FC, Miranda AE, Silveira MF. LBW and IUGR temporal trend in 4 population-based birth cohorts: the role of economic inequality. 2016 [cited 2019 Jun 21]; Available from: https:/ /bmcpediatr.biomedcentral.com/track/pdf/10.1186/ s12887-016-0656-0 